\title{
Energy demand analysis of mechanized transplanting system of tomato
}

\section{Análise da demanda energética de um sistema mecanizado de transplantio de tomate}

\section{Túlio de Almeida MACHADO1;2; Fábio Lúcio SANTOS³; Domingos Sárvio Magalhães VALENTE4; Haroldo Carlos FERNANDES ${ }^{5}$; Marconi Ribeiro FURTADO JÚNIOR ${ }^{6}$}

\author{
${ }^{1}$ Parte da dissertação de mestrado do primeiro autor; Pesquisa financiada pela Coordenação de Aperfeiçoamento de \\ Pessoal de Nível Superior \\ ${ }^{2}$ Autor para correspondência; Mestre em Engenharia Agrícola; Instituto Federal Goiano - Campus Morrinhos; \\ Departamento de Agropecuária; Br 153, Km 633, Zona Rural, Caixa Postal 92, Morrinhos-GO, CEP 75650-000; \\ machado.tulio@gmail.com \\ ${ }_{3}^{3}$ Doutor em Engenharia Agrícola; Universidade Federal de Lavras; ffabiolss@gmail.com \\ ${ }^{4}$ Doutor em Engenharia Agrícola; Universidade Federal de Viçosa; valente@ufv.br \\ 5 Doutor em Engenharia Agrícola; Universidade Federal de Viçosa; haroldo@ufv.br \\ ${ }^{6}$ Doutor em Engenharia Agrícola; Universidade Federal de Viçosa; marconi.junior@ufv.br
}

Recebido em: 17-10-2014; Aceito em: 11-05-2016

\begin{abstract}
Tomato culture has great importance among vegetable crops, and Brazil is the 5th largest producer worldwide. Faced with an increasing mechanization in this culture, this study aimed at evaluating the energy demand in fertilization and transplanting operations to the implementation of tomato crop. The study was conducted at Santa Rosa farm, in the municipality of Morrinhos - GO. The experimental design was a randomized block with four replications, combined three displacement speeds and three engine speeds in each operation. The traction force, the power in draw bar, and time, specific and operational fuel consumptions were evaluated. The results showed that traction force and power had greater influence with increasing displacement speed. The traction force and power in fertilization operation were influenced by the depth of shanks. The power demand of mechanized sets has been changed by displacement speed, where used tractors proved to be oversized. There was a lower operational fuel consumption in the two fertilization and transplanting operations due to tractor over sizing.
\end{abstract}

Additional keywords: available power; fuel consumption; mechanized operations.

\begin{abstract}
Resumo
A cultura do tomate possui grande importância dentre as olerícolas, sendo o Brasil o 5o maior produtor mundial. Diante de uma crescente mecanização nessa cultura, este trabalho teve o objetivo de avaliar a demanda energética nas operações de adubação e transplantio para a implantação na cultura do tomate. $O$ estudo foi desenvolvido na fazenda Santa Rosa, no município de Morrinhos - GO. O delineamento experimental foi o em blocos casualizados, com quatro repetições, combinando-se três velocidades de deslocamento e três rotações do motor em cada operação. Avaliaram-se a força de tração, a potência na barra de tração e os consumos: horário, específico e operacional de combustível. Os resultados demonstraram que a força de tração e a potência apresentaram maior influência com o aumento da velocidade de deslocamento. A força de tração e a potência na operação de adubação foram influenciadas pela profundidade das hastes sulcadoras A demanda de potência dos conjuntos mecanizados foi alterada pela velocidade de deslocamento, onde os tratores utilizados se mostraram superdimensionados. O consumo operacional em ambas operações apresentou o mesmo comportamento, onde, nas maiores velocidades de deslocamento e menores rotações, houve menor consumo em função do superdimensionamento dos tratores.
\end{abstract}

Palavras-chave adicionais: consumo de combustível; operações mecanizadas; potência disponível.

\section{Introduction}

Currently, Brazil is the 5th largest producer of tomatoes in South America, leading the production, and in this region, the largest consumer market of its industrialized products. In 2015 the transplanted area was 56.69 thousand ha, whose total production was 3.672 million tons, with an average yield of $64.785 \mathrm{~kg} \mathrm{ha}^{-1}$. Among the Brazilian states with increased production, Goiás has a total production of 882.8 thousand tons, accounting for approximately $24 \%$ of national production (IBGE, 2015).

Collection of seedlings with quality is critical to project success. They are responsible for the development of crops and production, in addition to allow obtaining fruits with quality (Marcos Filho, 2005). Malformed seedling disables and affects the whole culture development, increasing its cycle and production losses (Echer et al., 2007). 
For mechanized system, it is primarily used a fertilizer distributor equipment with shanks in the corresponding spacing to seedling distribution system of mechanical transplanting. In the moment of fertilizer distribution, furrows are opened, and fertilizer is immediately applied.

The energy balance aims at establishing energy flows, identifying its total demand and efficiency, reflected by energy net gain and the ratio output/input, in addition to the amount needed to produce or to process one kilogram of a determined product. According to Bueno et al. (2000), its main objective is to translate production factors into units or energy equivalent, and intermediate consumption, allowing the construction of comparable indicators between each other, and thus enabling intervention in productive system in order to improve its efficiency.

The energy evaluation can be performed based on measurement of fuel consumption per hectare, the main technical reference indicator in efficiency assessment of tractor use, since it demonstrates the involvement of several variables that influence the overall yield of fuel transformation supplied to the engine for useful work performed by implement (Serrano, 2007).

During the execution of mechanized farming operations, part of the cost is attributed to the energy demand of the equipment, which is related to the operational yield capacity. According to ASABE (2006), the traction force required in sowing, including rolling resistance, should be approximately $3.4 \mathrm{kN}$ per row, varying $35 \%$ for more or for less.

According to McLaughlin et al. (2008), with an appropriate selection of tillage system and the correct adjustment of seeder-fertilizer combine, a reduction in energy demand of agricultural machinery is obtained. By evaluating the energy consumption of different mechanized agricultural operations, Fernandes et al. (2008) concluded that tillage systems, with fewer operations per area, had lower fuel time consumption.

Authors, as Gabriel Filho et al. (2010), stud-

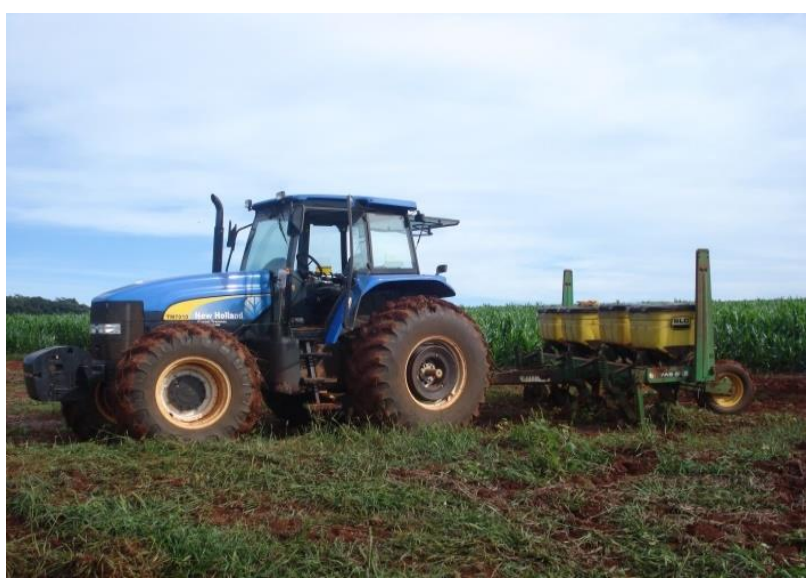

Figure 1 - Mechanized set used for fertilization. ied the operational performance of agricultural tractors under different tillage systems as well as Silva et al. (2008) who evaluated the performance of pickup machine combine in bean harvesting operation, however in none case, tools which maintain the quality of operations were used.

There are few studies on mechanization in the tomato crop, which led to the realization of an energy demand study to determine traction force, power and fuel consumption parameters. Therefore, this study aimed at determining the energy demand in the fertilizer and transplanting stages of the industrial tomato crop under three different displacement speeds and three engine speeds.

\section{Material and methods}

This study was conducted at Santa Rosa farm, located in the municipality of Morrinhos, Goiás. The average altitude is $770 \mathrm{~m}$. The longitude and latitude are $17^{\circ} 44^{\prime} 31.7^{\prime \prime S}$; 4903'12.6"W respectively. The property has a total area of 290 ha, with the experimental area limited to $58 \mathrm{ha}$, under a central pivot, with flat and slightly tilted relief (4\%), water content in soil around 30\% and Dystrophic Red Yellow Argisol soil type (Embrapa, 2013).

The equipments used to carry out the transplanting steps were separated regarding its fertilizing and transplanting operations. For the fertilization operation a New Holland TM 7010 model $4 \times 2$ TDA tractor was used, with power of $141 \mathrm{hp}$ (104 kW) pulling one SLC, 7AS-2 model precision fertilizer for tillage, with four fertilizer units, spaced $1.2 \mathrm{~m}$ between rows. For transplanting operation, mechanized set was consisted of the same tractor used to pull the fertilizer, however, when pulled, using a hydraulic lift system, a transplanting Ferrari brand, FX model for no-tillage, with four units of transplanting spaced $1.2 \mathrm{~m}$ between rows, with a capacity for 36 trays and mass of $630 \mathrm{~kg}$. The mechanized set used for fertilization is shown in Figure 1 and the set used for transplanting is presented in Figure 2.

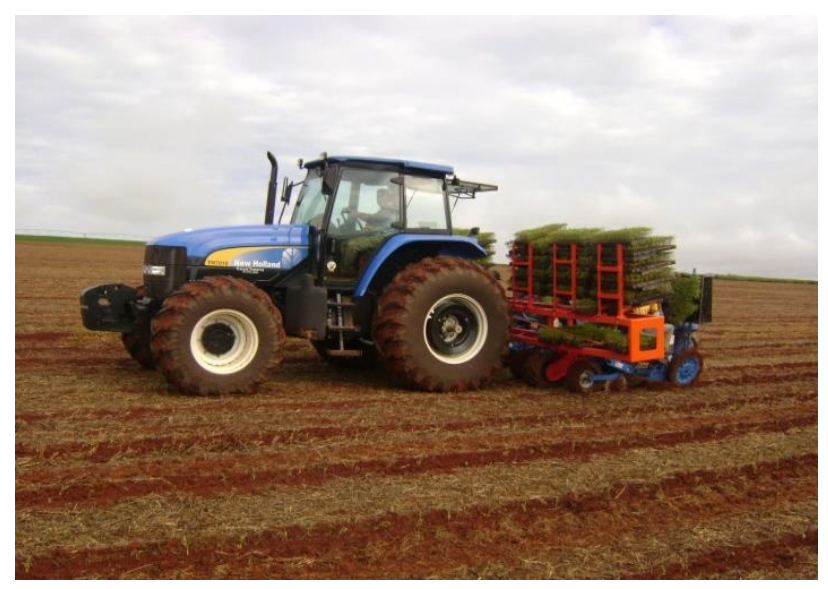

Figure 2 - Mechanized set used for transplanting. 
For both operations the following variables were determined: traction force, power demand, and time, specific and operational fuel consumptions.

The traction force of mechanized has been obtained with the aid of a load cell installed between the tractor and Kratoscom fertilizer with $50 \mathrm{kN}$ capacity, previously calibrated through hydraulic press with load cell measured by Instituto Nacional de Metrologia, Normalização e Qualidade Industrial (INMETRO). To determine the traction force required by transplanting, a "train" system was employed, whose constitution provides the use of two tractors, in which one is coupled to transplanting and another is used to pull the set. Through the difference between the traction force measured during the assay with transplanting and rolling traction, draft was obtained. This study was conducted in a no-till area, with a average slippage of the mechanized set of $6.8 \%$.

The power demanded by mechanized sets was calculated from displacement speed and traction force during operation, according to Equation 1.

$P=\frac{F S}{1000}$

Wherein $P$ is the required power $(\mathrm{kW}) ; F$ is the traction force $(\mathrm{N})$ and $S$ is the displacement speed of the operation $\left(\mathrm{m} \mathrm{s}^{-1}\right)$.

In order to measure fuel time consumption, the same methodology of Oliveira et al. (2007) was used, by the completion of tractor fuel tank to the maximum level; subsequently, tractor is connected and operation implemented (same closing work) and it was disconnect from itself. The deposit was restocked through a graduated cylinder with a capacity of one liter; and the spend volume was recorded in a worksheet.

The specific fuel consumption was determined by the ratio between fuel time consumption and the average Power required for draw bar, which was obtained by the product between force and average displacement speed, calculated according to Equation 2.

$\mathrm{S} c=\left[\left(\frac{T c}{P}\right) m\right] 1000$

Wherein $S c$ is the specific consumption $\left(\mathrm{g} \mathrm{kW}^{-1} \mathrm{~h}^{-1}\right)$, $T c$ é is the time consumption based on volume $\left(\mathrm{L} \mathrm{h}^{-1}\right), P$ is the power in drawbar $(\mathrm{kW})$ and $m$ is Diesel fuel specific mass $\left(0.853 \mathrm{~g} \mathrm{~mL}^{-1}\right)$.

Operational consumption was determined from the specific fuel consumption and the worked area during operations, as shown by Equation 3 .

$O c=\frac{T c}{E f C}$

Wherein $O c$ is the operational consumption $\left(\mathrm{L} \mathrm{ha}^{-1}\right)$, Tc time consumption $\left(\mathrm{L} \mathrm{h}^{-1}\right)$; and Efc is the effective field capacity $\left(\right.$ ha $\left.\mathrm{h}^{-1}\right)$.

The acquisition of the traction force data was performed using data acquisition Hottinger Baldwin Messtechnik (HBM), Spider $8^{\circledR}$ model, managed by HBM Catman ${ }^{\circledR} 2.2$ software installed on a laptop placed in the tractor.

For fertilization and transplanting operations, two experiments in a factorial design, according to randomized blocks with four replications were performed; whose plots had $50 \mathrm{~m}$ length (Figure 3). The factors evaluated were: displacement speeds (2.59, 3.20 and $3.60 \mathrm{~km} \mathrm{~h}^{-1}-\mathrm{V} 1$, V2 and $\mathrm{V} 3$ respectively) and different engine speeds $(1800,2000$ and $2200 \mathrm{rpm}$ - N1, N2 and N3 respectively). Data related to assessed variables (traction force, power and times, specific and operational fuel consumptions), for both operations were subjected to analysis of variance. The means corresponding to the factors were analyzed using regression models, which were selected, based on determination coefficient and significance of regression coefficients using $\mathrm{T}$ test at $5 \%$ and $10 \%$ of probability.

\begin{tabular}{|c|c|c|c|}
\hline V3N2 & V2N2 & V2N1 & V3N3 \\
\hline V1N2 & V3N1 & V3N3 & V2N2 \\
\hline V1N1 & V2N3 & V1N2 & V1N2 \\
\hline V2N3 & V1N1 & V1N3 & V1N1 \\
\hline V2N1 & V1N3 & V2N2 & V2N3 \\
\hline V3N1 & V1N2 & V3N1 & V1N2 \\
\hline V3N3 & V1N2 & V1N1 & V2N1 \\
\hline V1N3 & V2N1 & V1N2 & V3N1 \\
\hline V2N2 & V3N3 & V2N3 & V1N3 \\
\hline Block 1 & Block 2 & Block 3 & Block 4 \\
\hline
\end{tabular}

Figure 3 - Arrangement of randomized blocks.

\section{Results and discussions}

Table 1 shows the models found in fertilization and transplanting operations due to rotation and displacement speed factors for traction force $(F)$, power (P), time consumption (Tc), specific consumption (Sc) and operational consumption (Oc) variables. It was found that only time consumption and operational consumption factors were not significant at the $5 \%$ of probability. 
Table 1 - Results for the analysis of variance, considering the interaction between operational displacement speed and engine rotation speed factors and models obtained from regression analysis for fertilization and transplanting operations.

\begin{tabular}{cll}
\hline Analyzed variable & \multicolumn{1}{c}{ Fertilization } & \multicolumn{1}{c}{ Transplanting } \\
\hline$F$ & $F=15629.51-277.93 \mathrm{~V}-0.82 \mathrm{~N}^{*}$ & $F=7614+1807 \mathrm{~V}-3.88 \mathrm{~N}^{*}$ \\
$P$ & $P=8.32-0.18 \mathrm{~V}-0.00085 \mathrm{~N}^{*}$ & $P=-5.07+1.2 \mathrm{~V}+0.002 \mathrm{~N}^{*}$ \\
$T C$ & $T C=9.65+1,55 \mathrm{~V}+0.01 \mathrm{~N}$ & $T C=1.99+0.5 \mathrm{~V}+0.005 \mathrm{~N}^{* *}$ \\
$S c$ & $S c=-1719+261 \mathrm{~V}+1.45 \mathrm{~N}^{*}$ & $S c=8948.4-788.9 \mathrm{~V}-1.4 \mathrm{~N}^{*}$ \\
$O c$ & $O c=15.64-3.96 \mathrm{~V}+0.005 \mathrm{~N}$ & $O c=15.64-3.9 \mathrm{~V}+0.005 \mathrm{~N}^{* *}$ \\
\hline$V$ Displacement speed; $N=$ Engine rotation speed; ${ }^{*}$ Significant at $5 \%$ of probability** Significant at $10 \%$ of probability.
\end{tabular}

In fertilization and transplanting, traction force, power, and specific fuel consumption variables showed significance in the interaction of factors analyzed at $5 \%$ of probability. Similarly, the time and the operational fuel consumptions were only significant at $10 \%$ of probability. For this significance level there was an interaction between the rotation speed and displacement speed factors in those assessed variables.
Figure 4 shows the response surface for traction force due to rotation and displacement speed for fertilization operation. In this scenario, traction force had its lowest values when rotation and displacement speed were at maximum, thus obtaining a value of $13,000 \mathrm{~N}$. When values of rotation and displacement speed decreased, traction force tended to increase the demand where reached significantly values of $13,500 \mathrm{~N}$.

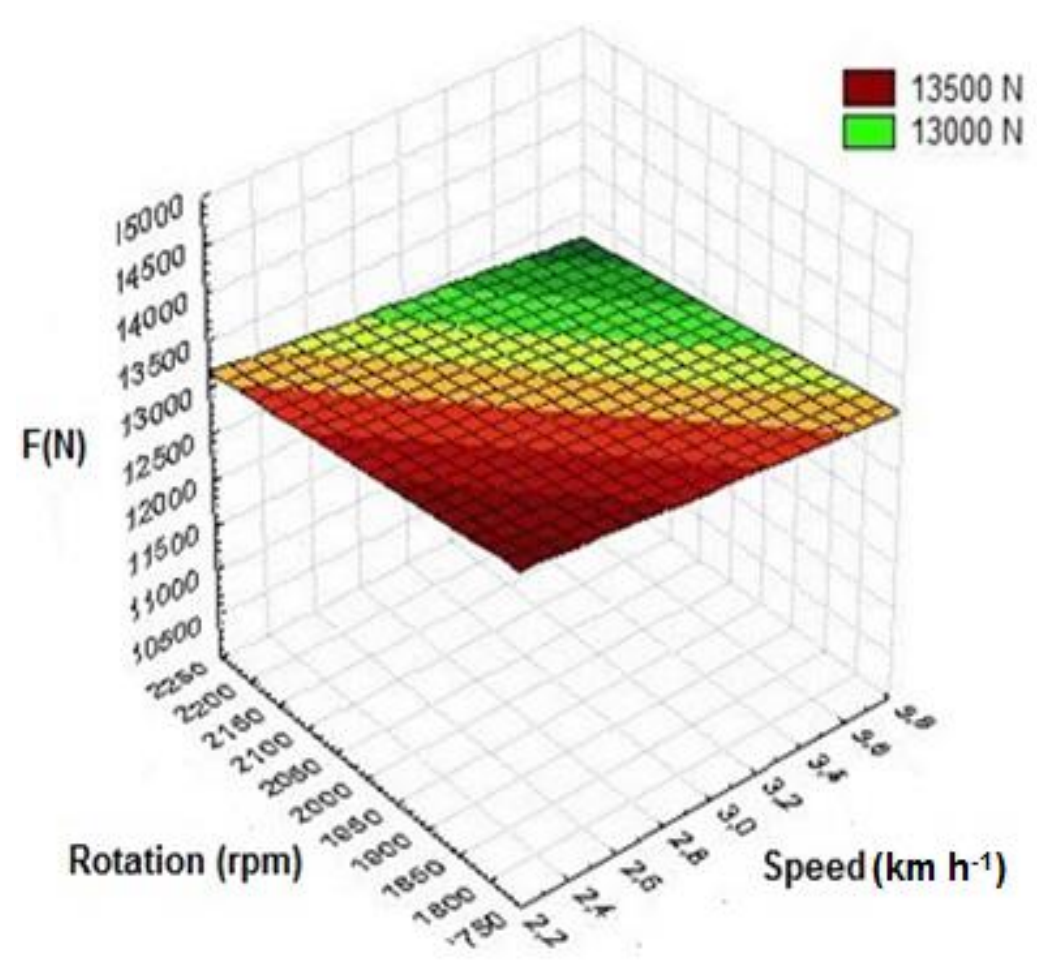

Figure 4 - Traction force $(F)$ required in fertilization operation.

Although there is no great difference between maximum and minimum values on the values found, they were significant. For lower values, there was an increase of the traction force. However, this increase tends to be more influenced by the depth of fertilizer shanks that worked to a greater depth than the transplanting operation.

This behavior was also found by Cepik et al. (2005), when evaluated that the specific traction force required by shank was not influenced by displacement speed of seeder-fertilizer combine in any of the water content in soil, being higher in the $12 \mathrm{~cm}$ depth in a dry and friable soil and with no difference with humid soil. Silveira et al. (2005) also found increased traction demand, with an increase of sowing depth with continuous flow seeders.

The required traction force in transplanting operation is shown in Figure 5, where a minimum value of $4,000 \mathrm{~N}$ and maximum values of $7,000 \mathrm{~N}$ were obtained. 


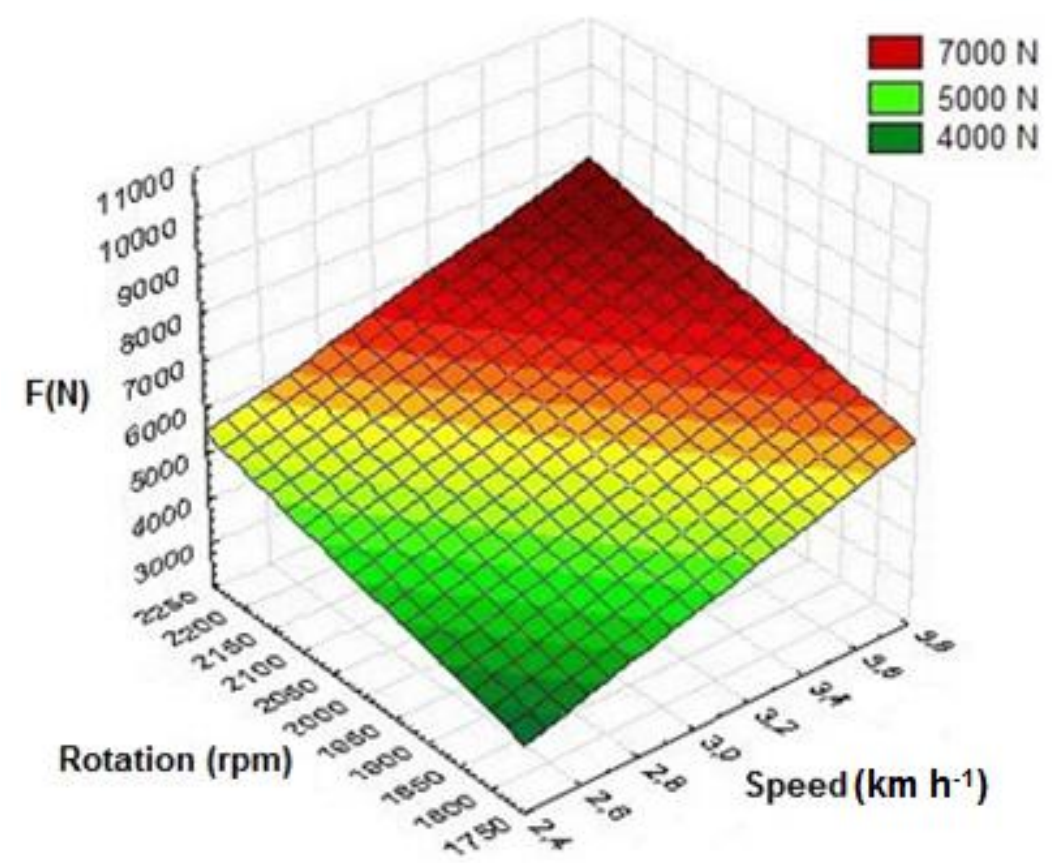

Figure 5 - Traction force $(F)$ required in transplanting operation.

The lower traction force for transplanting operation can be explained because it is a complementary equipment operation that works at a depth and lower displacement speed, requiring less engine tractor power. In this context, the displacement speed was the factor that obtained the greatest influence on the demand of the required force for implement traction.

Siqueira et al. (2013) characterized different Diesel fuel oil mixtures and reused soybean oil and evaluated the performance, on draw bar, of an agri- cultural tractor of tires and concluded that traction force increased as long as the enhance of operation speed. Bortolotto et al. (2006) evaluated a seederfertilizer combine in four speeds and three vegetation covers and observed the increase of the traction force required by mechanized set due to increased speeds.

Figure 6 shows power behavior due rotation and displacement speed in fertilization operation. In this condition, power had its lowest values, reaching a minimum of $7 \mathrm{~kW}$ value when rotation and displacement speed showed higher values.

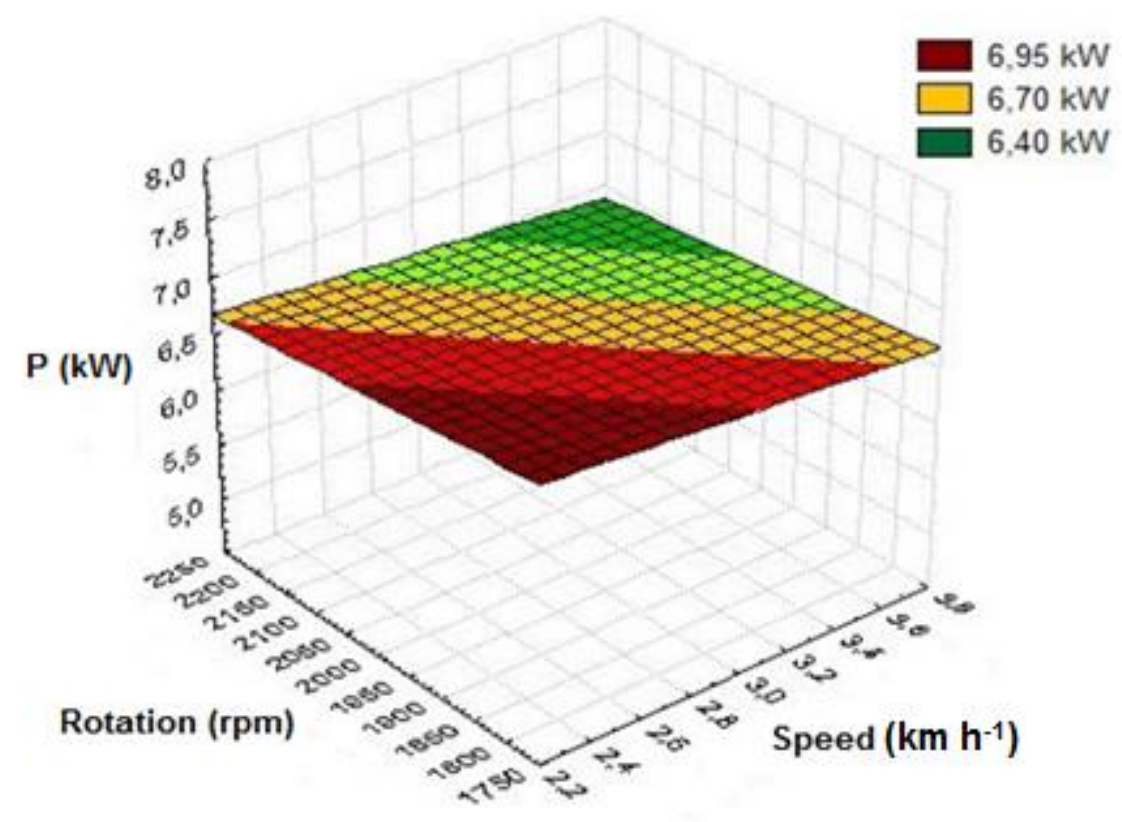

Figure 6 - Required power $(P)$ in fertilization operation. 
The implement power demand for fertilization followed traction force models for the same operation where at higher speeds and rotations lower required power values were obtained. This behavior can be assessed by the fact that there was one tractor with a high engine power and as thus, it reaches its maximum torque at higher rotations, thus being able to develop a higher speed.

The behavior of power values is directly connected to the traction force behavior. In this way, in a study with oat sowing, Silveira et al. (2005) found that with increasing depth of deposition from 1.97 to $2.68 \mathrm{~cm}$, the traction force requirement increased from 3.78 to $5.51 \mathrm{~kW}$ and increased displacement speed from 5.24 to $7.09 \mathrm{~km} \mathrm{~h}^{-1}$, adding $6.9 \%$ in traction force requirement. This statement corroborates with this study, where is also observed a small increase of demanded power in relation to displacement speed.

Figure 7 shows power behavior in transplanting operation. In this case, the power obtained its smallest values when rotation and displacement speed were also lower. From the increased displacement speed and rotation, the power demand values tended to increase, and, according to the determined model, the most influential factor was the speed.

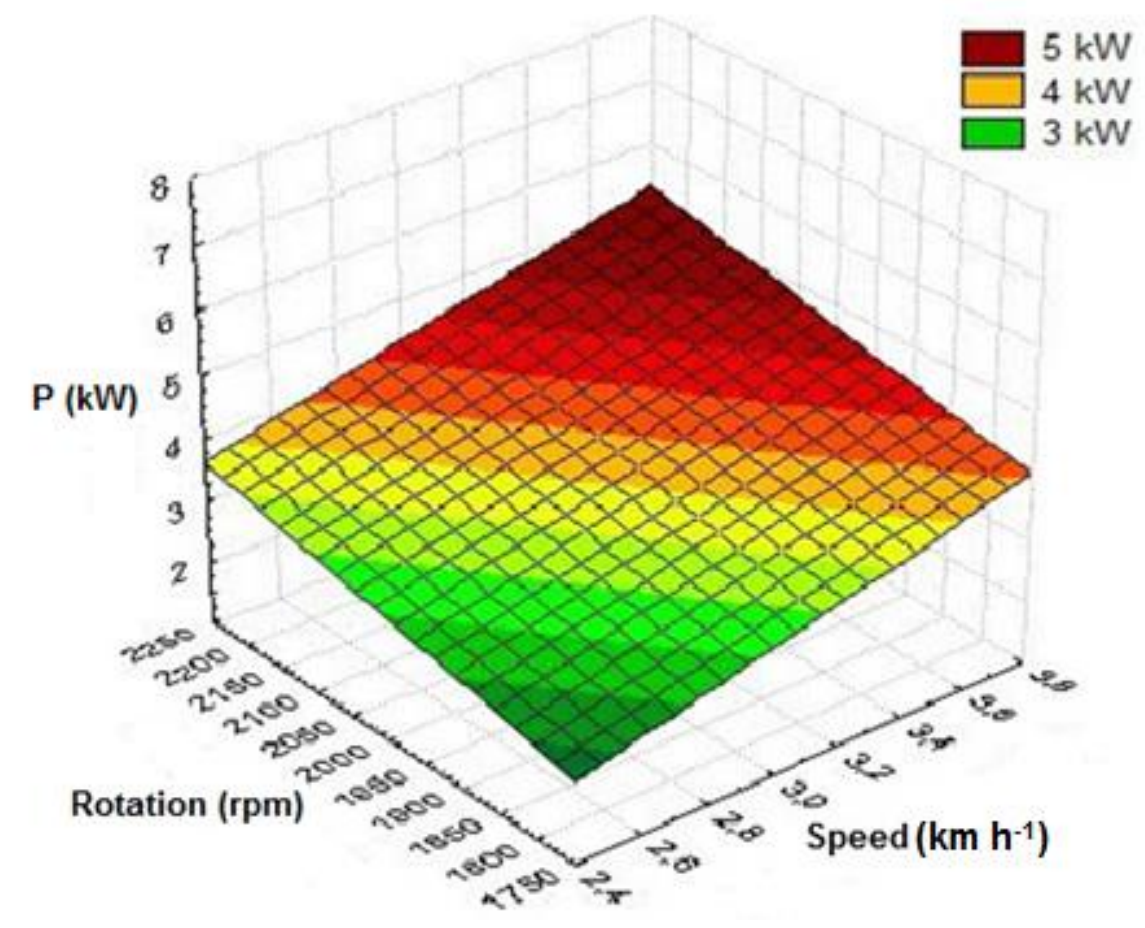

Figure 7 - Power required $(P)$ in transplanting operation.

The behavior can be reflected in this scenario, due to fertilization works in a greater depth of operation in the case of no-tillage, also promoting a first soil movement due to the fertilized rows. This did not occur with transplanting that was already working in the furrows made by the fertilizer, thus requiring less power.

The power required in transplanting operation was lower, reaching the minimum average value of 3 $\mathrm{kW}$ and a maximum of $5 \mathrm{~kW}$. The lower power requirement of transplantation can be explained because it is complementary operation equipment of fertilizer and for working in a smaller depth and at higher displacement speed, requiring less power from the tractor.

Given this behavior, this study is in agreement with the tendencies found by Bortolotto et al. (2006), that when analyzing the power required on the drawbar for a seeder with four displacement speeds in different vegetation cover, observed that the coverage condition with spontaneous vegetation was the one with higher power requirement while the desiccated and rolled oat did not differ between themselves.

On the same approach, Mahl et al. (2004) analyzed a seeder-fertilizer combine and found that there was a gradual increase in power with increasing displacement speed, so that when increased speed from 4.4 to $8.1 \mathrm{~km} \mathrm{~h}^{-1}$ there was an increase of $96 \%$ in power requirement.

In fertilization operation, fuel time consumption had no statistical significance in the interaction between speed of displacement and rotation factors. However, there was a trend of results to higher consumption with increased speed of displacement and rotation, as shown in Figure 8. If tractor was stopped with engine running, consumption would be minimum. 


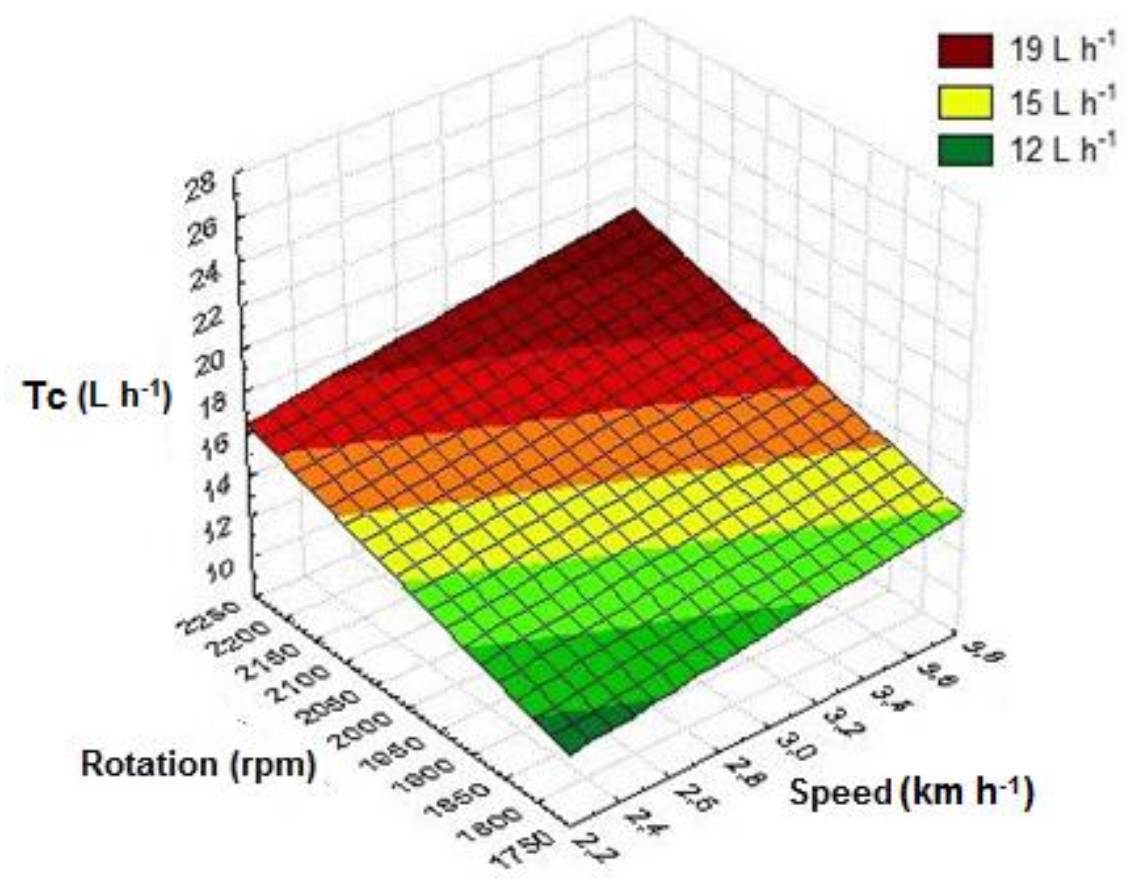

Figure 8 - Time fuel consumption $(T C)$ in fertilization operation.

From the increased rotation and displacement speed, the time consumption values tended to be higher, with peak consumption of up to $19 \mathrm{~L} \mathrm{~h}^{-1}$. In studies conducted by Almeida et al (2010), the rotation was the most influential factor for the time consumption, which found that when there was a low engine speed and gear that provided a speed below
$5.0 \mathrm{~km} \mathrm{~h}^{-1}$, there was also, a lower instantaneous, time and specific fuel consumption.

Figure 9 shows the response surface for time fuel consumption in transplanting operation, where the interaction of displacement speed and rotation factors were significant, and, as in fertilization operation, the rotation was the most influential factor.

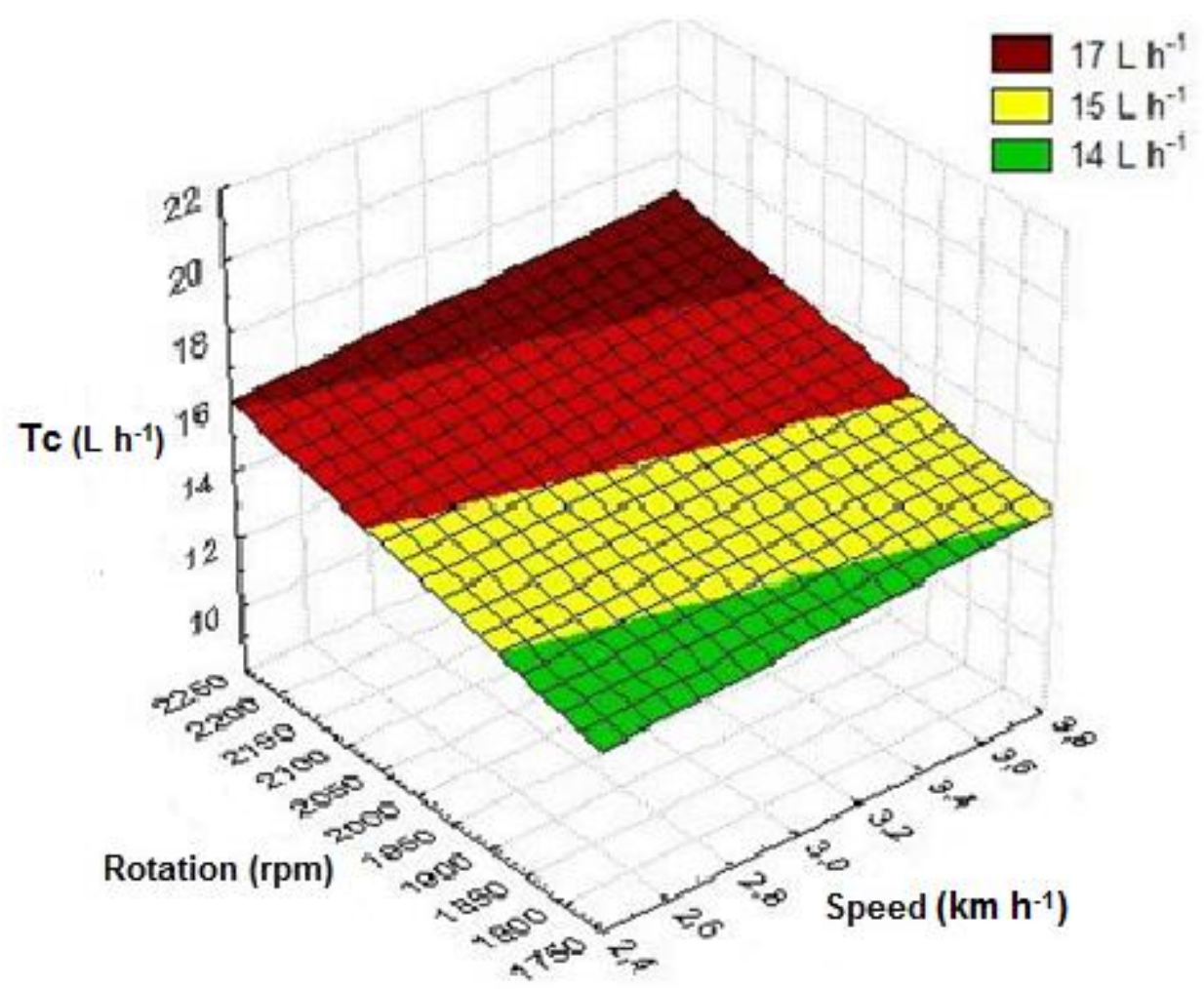

Figure 9 - Time fuel consumption $(T C)$ in transplanting operation. 
Time fuel consumption in transplanting operation was lower compared to fertilization operation, reaching the maximum value of $17 \mathrm{~L} \mathrm{~h}^{-1}$. This behavior had an increasing value, which, with increasing displacement speed and specially increased rotation, there was an increase on time consumption. By the provision of the response surface, it can analyze that rotation had greater influence than the speed on the time fuel consumption in transplanting, due to the fact that as classes are separated almost along the axis of rotation.
By maintaining the same operational speed and reducing rotation of engine axis, Grogan et al. (1987) reduced the time fuel consumption by $17 \%$. Silva et al. (2003), alternating the engine rotation, found an increase of $71 \%$ in the time fuel consumption, with a single tractor engine in corn sowing operation.

Figure 10 shows specific fuel consumption due to rotation and speed at fertilization operation. In this condition, the variable obtained its values reaching the minimum value of $1,400 \mathrm{~g} \mathrm{~kW} \mathrm{~h}^{-1}$ and higher values of $2,400 \mathrm{~g} \mathrm{~kW} \mathrm{~h}^{-1}$.

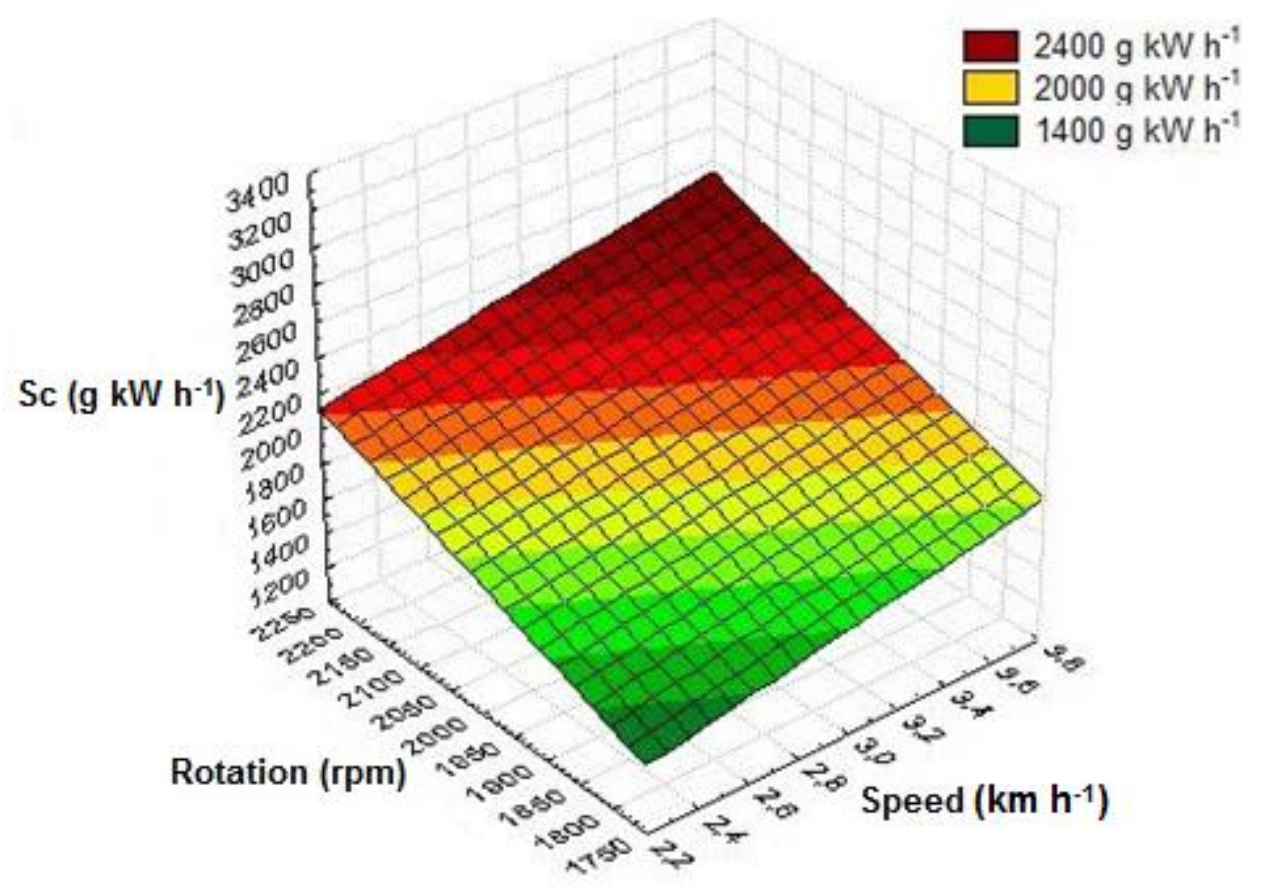

Figure 10 - Specific fuel consumption (Sc) in fertilizer operation.

Almeida et al. (2010) evaluated the energetic performance of a tractor and a precision seeder of notillage operation in the implementation of maize crop (Zea mays L.), where different gears and engine rotations were considered and concluded that by employing a higher engine rotation, there was a considerable increase in specific fuel consumption.

Figure 11 shows the specific fuel consumption in transplanting operation. In this case, there were lower values when rotation and displacement speed had higher average values $\left(4,000 \mathrm{~g} \mathrm{~kW} \mathrm{~h}^{-1}\right)$. From the reduction of displacement speed and increased rotation, there was an increase for fuel consumption values.

Specific fuel consumption in transplanting operation was higher, reaching the maximum average value of $4,567 \mathrm{~g} \mathrm{~kW} \mathrm{~h}^{-1}$ while consumption in fertilizer operation reached the maximum of $2,400 \mathrm{~g} \mathrm{~kW} \mathrm{~h}^{-1}$. This behavior shows that the specific consumption in transplanting operation is greater than that obtained in fertilization operation. This may be explained due to better use of power in fertilization operation, resulting in lower fuel consumption. Thus, the greatest specific consumption in transplantation use can be explained because it is an implement that demanded lower traction force and power, thus generating a greater specific consumption.

These results corroborate to those found by Cortez et al. (2007), in which lower values of specific fuel consumption are obtained at higher operating speeds. Silveira (2008) found that the increase in speed from 3.5 to $7.0 \mathrm{~km} \mathrm{~h}^{-1}$, in a same engine speed, showed a reduction in specific fuel consumption.

The behavior found for the specific consumption was the same found by Masiero et al. (2010), where it was found that as increased displacement speed of tractor, greater the time fuel consumption and lower specific fuel consumption on average.

A similar result was obtained by Furlani et al. (2008) when evaluating the performance of a seeder-fertilizer combine found that the specific fuel consumption was higher when working at lower operating speeds, a fact explained by lower demand in the drawbar, as the power required by the system is a determining factor for obtaining this variable. 


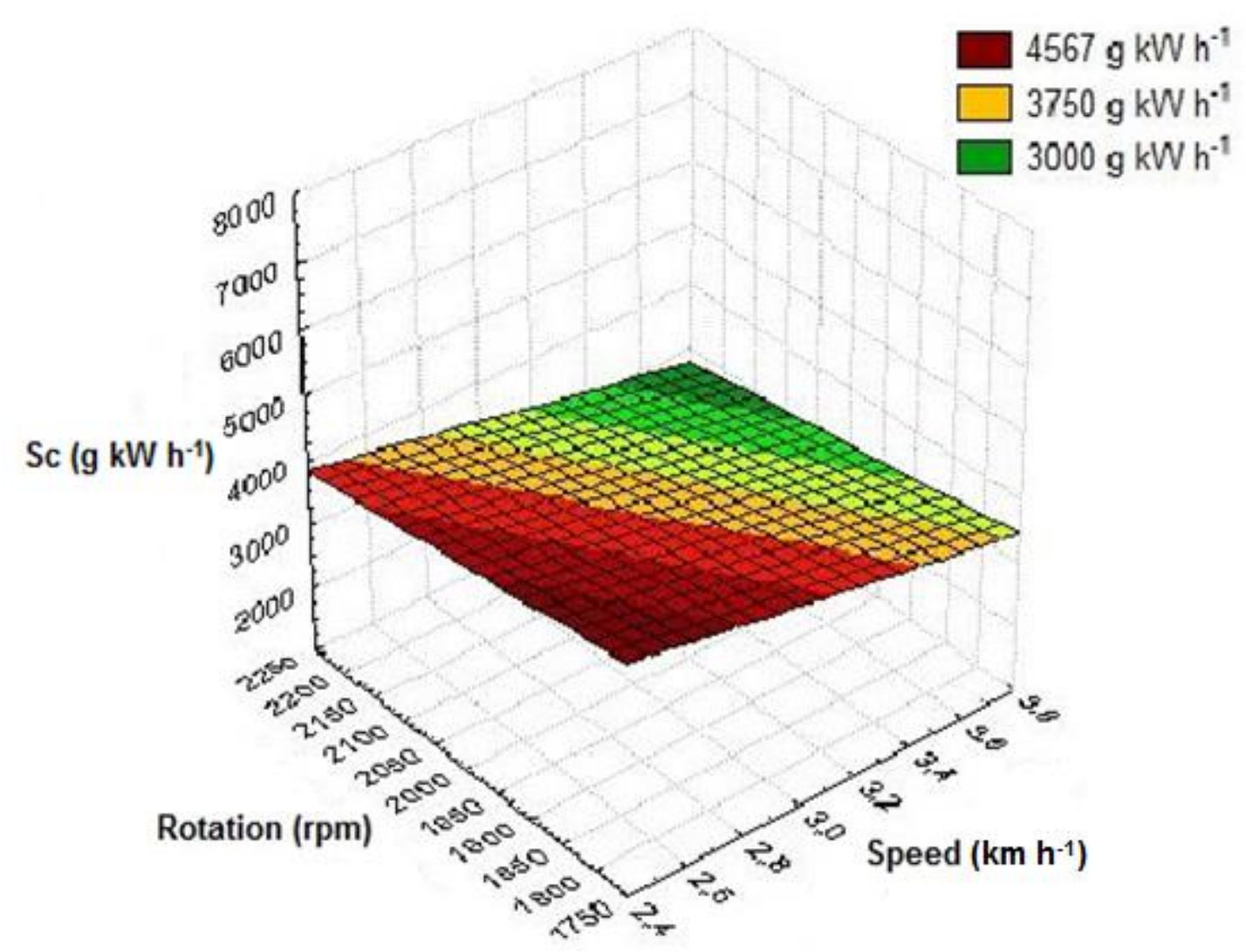

Figure 11 - Specific fuel consumption (Sc) in transplanting operation.

It is evidenced the possibility of working with smaller rotations and appropriate speeds according to gear scaling in order to efficiently use the fuel, not only in tillage operations, but also in sowing operations.

In Figure 12, operational fuel consumption in fertilizer operation had no statistical significance in the interaction of the analyzed factors. However, as in the time consumption variable, there was a trend of operational consumption values for different speeds of displacement and rotation.

In fertilization operation, the operational fuel consumption for the maximum displacement speed values and minimum for rotation studied was $10 \mathrm{~L} \mathrm{ha}{ }^{1}$. However, according to increased rotation and lower displacement speed, this factor has tended to increase, turning consumption reaches until $18 \mathrm{~L}$ $\mathrm{ha}^{-1}$. This behavior was mainly influenced by rotation, because influence on the rise of values is greater than that found based on displacement speed.

Mahl et al. (2004) found that regarding the variation of displacement speed of seeder-fertilizer combine, there was no effect on the fuel consumption and the effective field capacity and as long as speed increased, there was significant reduction in the operational fuel consumption and increased effective field capacity.

Figure 13 shows operational fuel consumption in transplanting operation, where there was a trend of results with increased rotation values and decreased displacement speed.

In transplanting operation, the operational fuel consumption for the maximum values of displacement speed minimum for the rotation studied was $10 \mathrm{~L} \mathrm{ha}^{-1}$. However, in accordance with an increasing rotation and decreased speed, this factor has tended to increase; turning consumption reaches $16 \mathrm{~L} \mathrm{ha}^{-1}$ when there was a lower displacement speed and higher rotation values.

This behavior, as well as fertilization operation, is mainly influenced by rotation, because influence on the rise of values is greater than speed values. However, the fuel consumption for average maximum values in transplanting operation was lower than values found in fertilization operation, thus transplanting operation is more economical when set to maximum operations and speeds.

Lyra et al. (2012) evaluated two harvesters of sugarcane in three different displacement speeds and three engine speeds and concluded that displacement speed influence fuel consumption per harvested area.

The higher the operation speed, the lower the fuel consumption per worked area, that is correlated to the theoretical operational capacity, i.e., at a lower operational theoretical capacity there is a higher fuel consumption per worked area. 


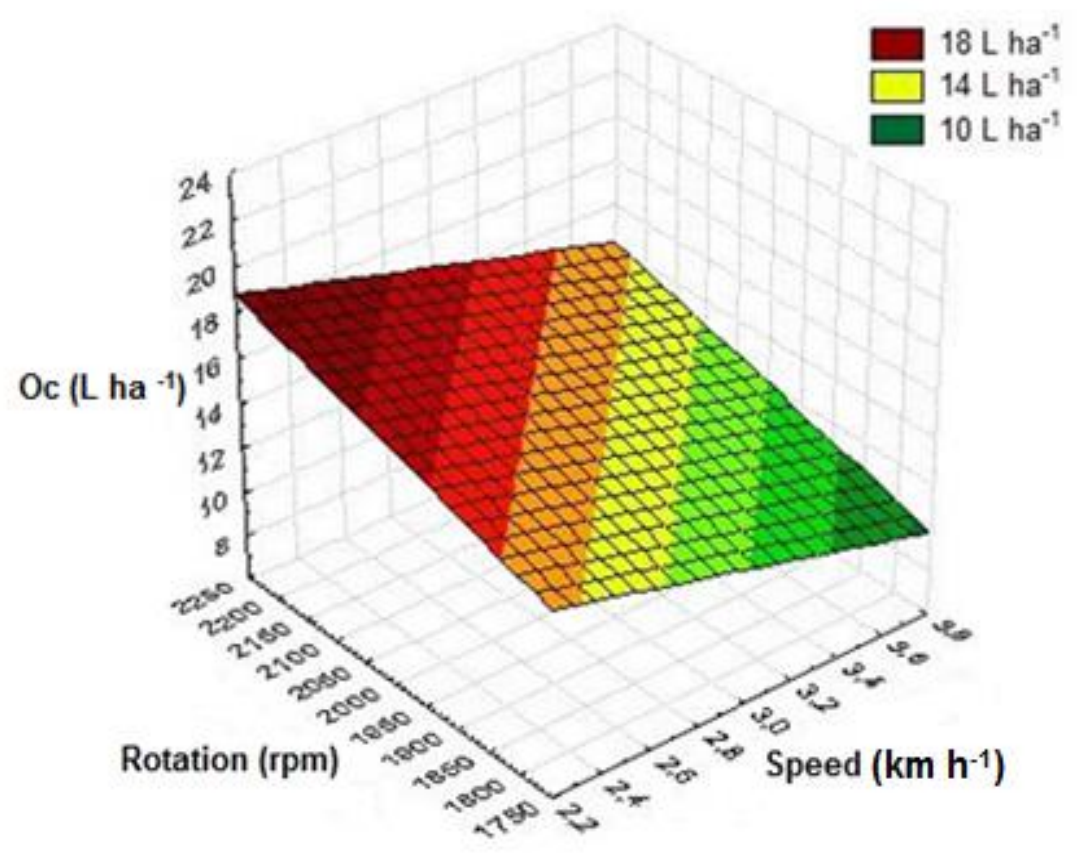

Figure 12 - Operational fuel consumption $(O c)$ in fertilization operation.

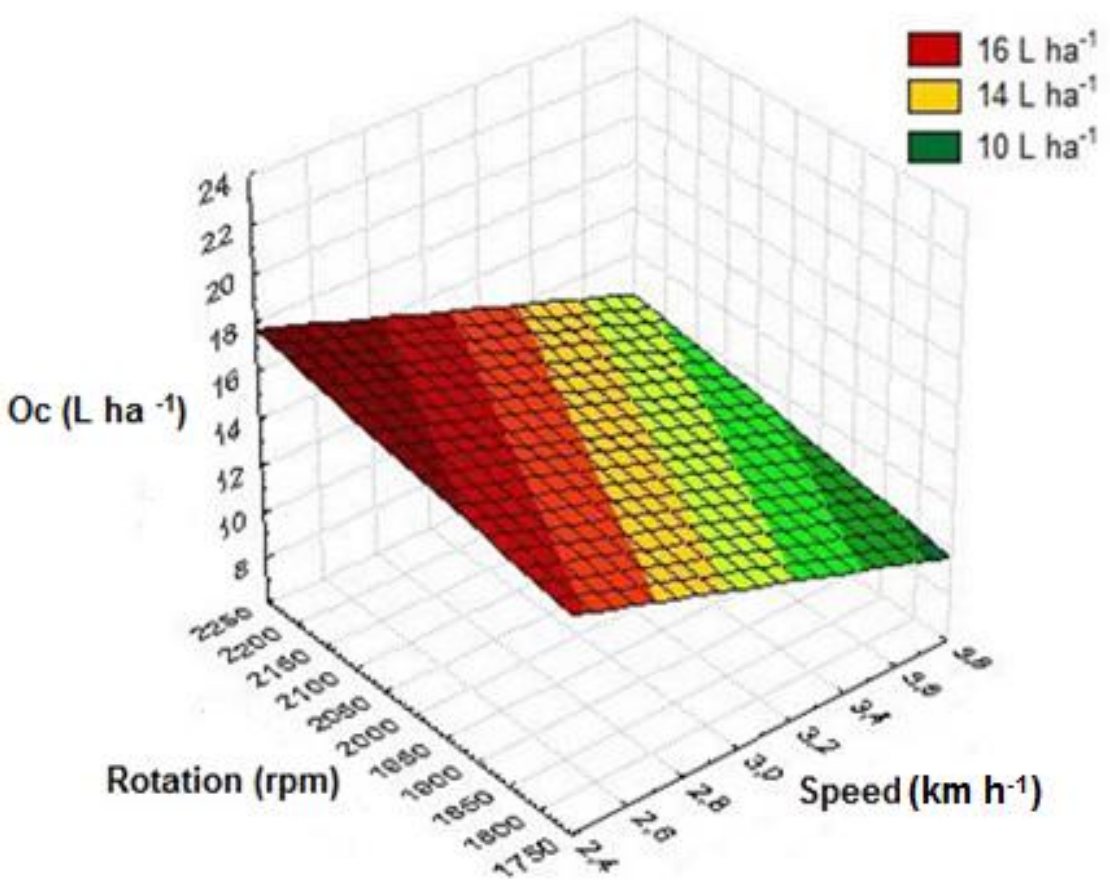

Figure 13 - Operational fuel consumption $(O c)$ in transplanting operation.

\section{Conclusion}

The conditions where experiment was conducted it can be concluded that traction force and power in fertilization operation were more influenced by the depth of fertilizer shanks. The power of the mechanized sets obtained greater influence of displacement speed regarding increased values for

\section{transplanting operation.}

The consumption achieved its highest values with increased rotation and displacement speed. Operational fuel consumption of both operations obtained the same behavior, in which, at higher speeds and lower speeds of displacement there was the lower fuel consumption. 


\section{References}

Almeida RAS, Silva CAT, Silva SL (2010) Desempenho energético de um conjunto trator-semeadora em função do escalonamento de marchas e rotações do motor. Revista Agrarian 3(7):63-70.

ASABE - American Society of Agricultural and Biological Engineers (2006) ASAE D497.5: Agricultural machinery management data. In: ASABE standards. p.391-398.

Bortolotto VC, Pinheiro Neto R, Bortolotto MC (2006) Demanda energética de uma semeadora-adubadora para soja sob diferentes velocidades de deslocamento e coberturas do solo. Engenharia Agrícola 26(1):122-130.

Bueno, OC, Campos, AT, Campos, AT. (2000). Balanço de energia e contabilização da radiação global: simulação e comparativo. In: Avances en Ingeniería Agrícola. Buenos Aires: Editorial Facultad de Agronomia, p.477-82.

Cepik CTC, Trein CR, Levien R (2005) Força de tração e volume de solo mobilizado por haste sulcadora em semeadura direta sobre o campo nativo, em função do teor de água no solo, profundidade e velocidade de operação. Engenharia Agrícola 25(2):447-457.

Cortez JW, Furlani CEA, Silva RP, Grotta DCC, Reis GN (2007) Consumo de energia na operação de semeadura em plantio direto. In: congresso brasileiro de engenharia agrícola, 36.

Echer MM, Guimarães VF, Aranda NA, Bortolazzo ED, Braga JS (2007) Avaliação de mudas de beterraba em função do substrato e do tipo de bandeja. Semina: Ciências Agrárias 28(1):45-50.

Embrapa - Empresa Brasileira de Pesquisa Agropecuária (2013). Centro Nacional e Pesquisa em Solos. Sistema brasileiro de classificação de solos. Brasília, 306p.

Fernandes HC, Silveira JCM, Rinaldi PCN (2008) Avaliação do custo energético de diferentes operações agrícolas mecanizadas. Ciência e Agrotecnologia 32(5):1582-1587.

Furlani CEA, Silva RP, Carvalho Filho A, Cortez, JW, Grotta DCC (2008) Semeadora-adubadora: exigências em função do preparo do solo, da pressão de inflação do pneu e da velocidade. Revista Brasileira de Ciência do Solo 32(1):345-352.

Gabriel Filho A, Lanças KP, Leite F, Acosta JJ, Jesuíno PR (2010) Desempenho de trator agrícola em três superfícies de solo e quatro velocidades de deslocamento. Revista Brasileira de Engenharia Agrícola e Ambiental 14(3):333-339.

Grogan J, Morris DA, Searcy SW, Stout BA (1987) Microcomputer based tractor performance system. Journal of Agricultural Engineering Research 38(4):227-43.
IBGE - Instituto Brasileiro de Geografia e Estatística (2015) Levantamento Sistemático da Produção Agrícola 29(11):1-85.

Lyra GA, Lanças KP, Ramos RCG, Giachini CF, Masiero FC (2012) Influência dos implementos de limpeza no consumo de combustível das colhedoras de cana-de-açúcar. In: Congresso Brasileiro de Engenharia Agrícola 41.

Marcos Filho J (2005) Fisiologia de sementes de plantas cultivadas. FEALQ. 495 p.

McLaughlin NB, Drury CF, Reynolds WD, Yang XM, Li YX, Welacky TW, Stewart G (2008) Energy inputs for conservation and conventional primary tillage implements in a clay loam soil. Transactions of the ASABE, 51(4):1153-1163.

Mahl D, Gamero CA, Benez SL, Furlani CEA, Silva ARB (2004) Demanda energética e eficiência da distribuição de sementes de milho sob variação de velocidade de deslocamento e condição do solo. Engenharia Agrícola 24(1):150-157.

Masiero FC, Lanças KP, Machado TM, Saretta E (2010) Avaliação do consumo de combustível de um trator agrícola em função da velocidade de deslocamento e da variação de inflação dos pneus. In: Congresso Brasileiro de Engenharia Agrícola, 39.

Oliveira E, Silva FM, Guimarães RJ, Souza ZM (2007) Eliminação de linhas em cafeeiros adensados por meio semimecanizado. Ciência e Agrotecnologia 31(6):1826-1830.

Serrano JMPR (2007) Desempenho de tratores agrícolas em tração. Pesquisa Agropecuária Brasileira 42(7):1021-1027.

Silva RP, Reis LD, Reis GN, Furlani CEA, Lopes A, Cortez JW (2008) Desempenho operacional do conjunto trator-recolhedora-trilhadora de feijão. Ciência Rural 38(5):1286-1291.

Silva SL, Gabriel Filho A, Silveira JCM, Ricieri RP (2003) Redução do consumo de combustível em função da rotação no eixo do motor. In: Congresso Brasileiro de Engenharia Agrícola 32.

Silveira JCM, Modolo AJ, Silva SL, Gabriel Filho A (2005) Força de tração e potência de uma semeadora em duas velocidades de deslocamento e duas profundidades de deposição de sementes. Revista Brasileira de Engenharia Agrícola e Ambiental 9(1):125-128.

Silveira JCM (2008) Desempenho operacional de um conjunto trator-semeadura em função da velocidade e rotação no eixo do motor. 118 p.

Siqueira WDC, Fernandes HC, Teixeira MM, Santos NT, Abrahão SA (2013) Desempenho na barra de tração de um trator agrícola de pneus, alimentado com misturas de óleo diesel e óleo de soja reutilizado. Ceres 60(6):793-801. 